\title{
Evaluating the Cost of Drugs used in the Outpatient Treatment of Chronic Pain
}

\author{
Roberto Vlainich ${ }^{1}$, Paola Zucchi ${ }^{1}$, Adriana Machado Issy ${ }^{2}$, Rioko Kimiko Sakata ${ }^{3}$
}

Summary: Vlainich R, Zucchi P, Issy AM, Sakata RK - Evaluating the Cost of Drugs Used in the Outpatient Treatment of Chronic Pain.

Background and objectives: Chronic pain is very prevalent and the cost of its treatment can cause a relevant impact on people and society. The objective of this study was to evaluate the monthly cost of drugs used in the outpatient treatment of chronic pain.

Methods: In the present study the cost of the drugs used by 233 patients with chronic pain (117 with nociceptive pain, 59 with neuropathic pain, and 57 with mixed pain) followed at the Alpha Center of UNIFESP between January 2004 and January 2008 was evaluated.

Results: The mean general cost was $\mathrm{R} \$ 127.74$ (from $\mathrm{R} \$ 5.00$ to $\mathrm{R} \$ 780.00$ ).

Conclusions: This study showed that the cost of the drugs does not differ significantly taking into consideration the type of pain.

Keywords: DRUGS: costs.

[Rev Bras Anestesiol 2010;60(4): 399-405] CElsevier Editora Ltda.

\section{INTRODUCTION}

The increased efficiency of prevention in the treatment of diseases has resulted on increased life expectancy ${ }^{1}$. An increase in the expenses with equipment, material, and drugs has also evolved, leading to the development of techniques of health economy to evaluate the implications of the cost of pharmacotherapy.

The objective of pharmacoeconomic studies is to identify, quantify, and compare costs, besides evaluating economic, clinical, and humanistic consequences.

Costs can be classified as direct, indirect, and intangible ${ }^{2}$. Direct costs are those associated to medical care and drugs, while indirect costs are characterized by the loss of productive capacity of patients as consequence of morbidity or mortality. On the other hand, intangible costs are associated to pain and suffering, being more difficult to quantify and evaluate, since they consider the quality of life of individuals ${ }^{3}$. Besides measuring costs, pharmacoeconomics also analyses the economic and non-economic benefits, such as effects in the health and increase in life expectancy and quality of life ${ }^{4}$.

Received from the Anesthesiology, Pain, and Intensive Care Department of Escola Paulista de Medicina da Universidade Federal de São Paulo (EPM/UNIFESP), SP

1. Physician of the Alpha Center

2. Professor of the Anesthesiology, Pain, and Intensive Care Department of EPM/UNIFESP 3. Coordinator of the Pain and Intensive Care Department of EPM/UNIFESP, Physician Coordinator of the Pain Sector

Submitted on October 29, 2009

Approved on March 9, 2010

Correspondence to:

Dra. Rioko Kimiko Sakata

Rua Três de Maio, 61/51

Vila Clementino

04044-020 - São Paulo, SP

E-mail: riokoks.dcir@epm.br
The growing interest in quality of life led to a significant development of methods to evaluate it ${ }^{5}$. To obtain a more accurate result of the individual and collective evaluation of health states, a large number of tools have been proposed and validated all over the world ${ }^{6}$. Measurements of quality of life have several applications: screening and monitoring of psychosocial problems in individual care, populational studies on the perception of health states, medical auditing, measurement of results in health services, and clinical assays. It also includes economical analysis that focuses the costs to guarantee better quality of life (cost-usefulness) ${ }^{6}$.

Studies on the cost of diseases try to quantify economically their effects for the treatment of chronic pain.

The objective of this study was to evaluate the mean monthly costs of drugs used in the outpatient treatment of chronic pain.

\section{METHODS}

This is a retrospective, observational, and longitudinal study. After approval by the Research Ethics Committee, data from the records of patients with chronic pain (more than three months in treatment) were collected. Patients with nociceptive, neuropathic, or mixed pain that have been seen at the outpatient clinic of the Alpha Center from January 2004 to January 2008 were included in this study.

Mean monthly costs were calculated using a spreadsheet that considered the drugs, doses, routes of administration, and frequency of administration. The prices were calculated using the Brasindex table for September 2008, and they were analyzed by frequency measurements (mean, minimum, maximum, quartiles, and standard deviation). Quar- 
tiles, minimum, and maximum prices were also represented in box-plot charts.

The following statistical tests were used: Kruskal-Wallis, Kolmogorov-Smirnov, and Levene. A level of significance of $5 \%$ was adopted for all statistical tests. Analyses were done using the software SPSS 13.0.

\section{RESULTS}

Out of 233 patients with chronic pain, 117 had nociceptive pain, 59 had neuropathic pain, and 57 had mixed pain. Out of the total, $27.9 \%$ were males and the remaining were females (Table I).

The mean general cost was $R \$ 127.74$, with a minimum cost of $R \$ 5.00$ and a maximum cost of $R \$ 780.00$ were observed (Table II, Figure 1).

Homogeneity in the distribution of costs in the different types of pain was not observed, with a large concentration of patients with low costs and very few with elevated costs (Figure 2).

Analyzing mean costs, a difference (Kruskal-Wallis test; $p=0.3109$ ) according to pain classification was not observed (Table II and Figure 3). Figure 3 shows the mean costs and their respective 95\% confidence interval. Levene test indicated equal variance among the groups $(p=0.3546)$. Kolmogorov-Smirnov test and the quartile dispersion chart of a normal and the residues of ANOVA allowed the observation of a lack of normalcy of the data (Figure 4).

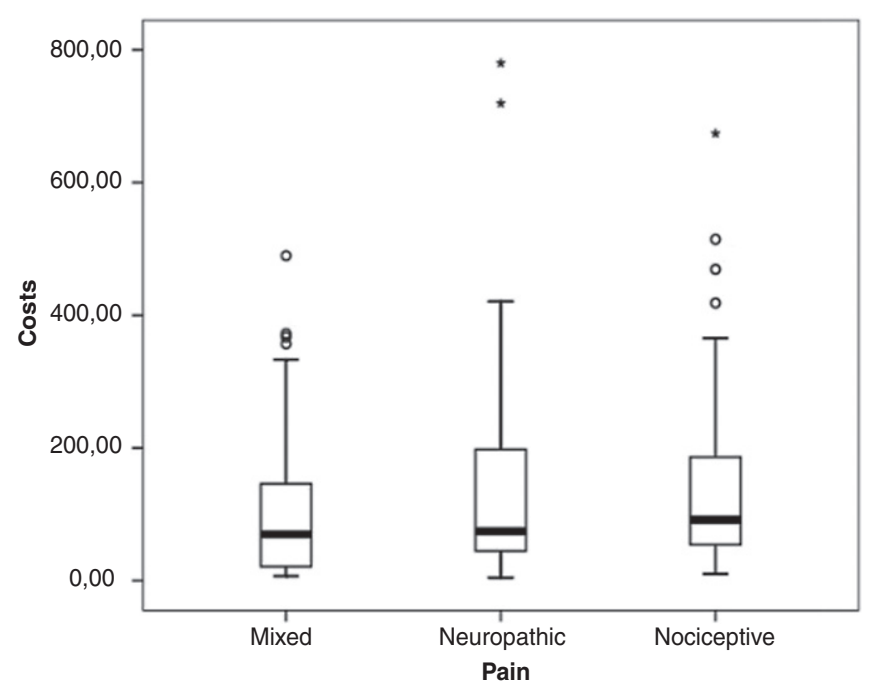

Figure 1 - Costs According to Type of Pain.
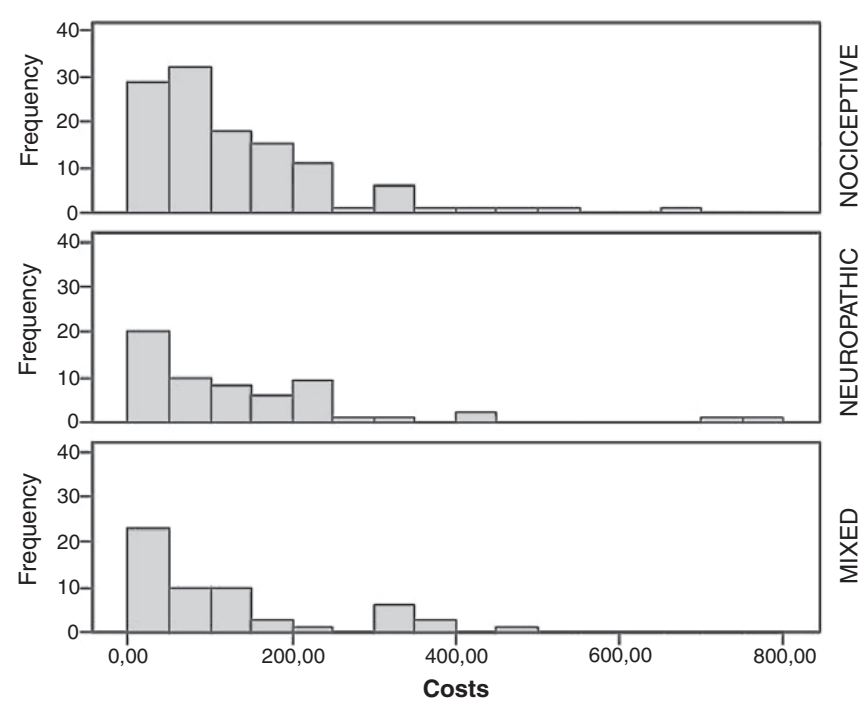

Figure 2 - Distribution of the Costs According to Pain Type.

Table I - Demographic Data of the Patients

\begin{tabular}{|c|c|c|c|c|}
\hline & \multicolumn{3}{|c|}{ Pain } & Total n (\%) \\
\hline Male & 27 (11.58) & 28 (12.02) & $10(4.30)$ & 65 (27.9) \\
\hline Total & $117(50.21)$ & 59 (25.32) & 57 (24.47) & $233(100)$ \\
\hline
\end{tabular}

Table II - Total Cost (in Reais) According to the Classification of Pain

\begin{tabular}{lllll}
\hline & \multicolumn{2}{c}{ Pain } & Mixed & Total \\
\cline { 2 - 4 } & Nociceptive & Neuropathic & $116.81 \pm 121.23$ & $127.74 \pm 125.64$ \\
Mean \pm SD & $127.17 \pm 113.7$ & $139.44 \pm 151.12$ & 16.06 & 8.23 \\
Standard deviation & 10.51 & 19.67 & {$[84.64 ; 148.98]$} & {$[111.53 ; 143.96]$} \\
$95 \% \mathrm{Cl}$ & {$[106.35 ; 147.99]$} & {$[100.06 ; 178.82]$} & 21.25 & 41.12 \\
$1^{\text {st }}$ quartile & 51.83 & 44.04 & 69.97 & 84.08 \\
Median & 91.70 & 74.28 & 153.49 & 186.12 \\
$2^{\text {nd }}$ quartile & 186.12 & 204.33 & 7.20 & 4.88 \\
Minimum & 9.77 & 4.88 & 489.72 & 779.96 \\
Maximum & 674.03 & 779.96 & 57 & 233 \\
$\mathrm{~N}$ & 117 & 59 & & \\
\hline
\end{tabular}

Kruskal-Wallis test $-c^{2}=2.34(p=0.3109)$. 


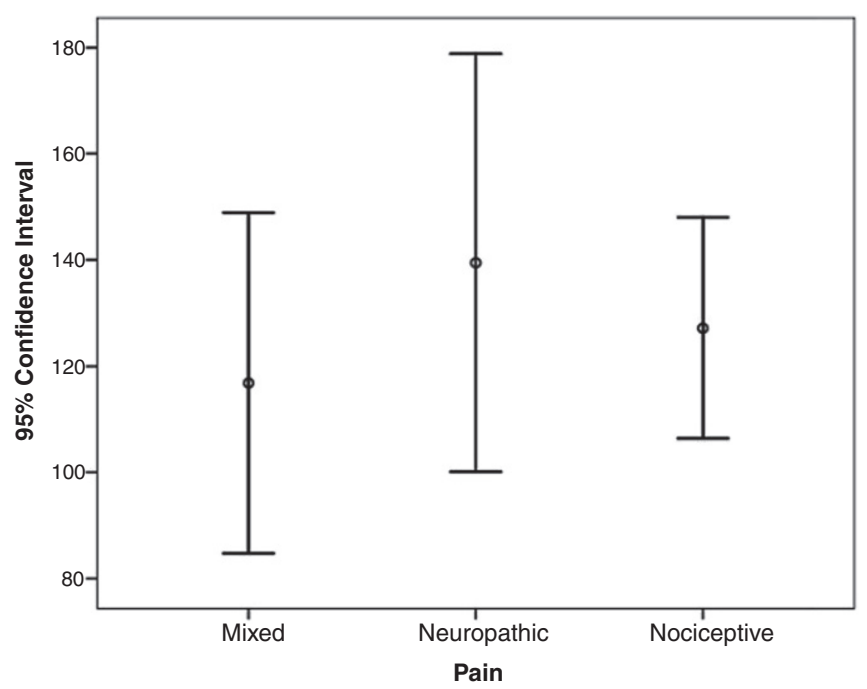

Figure 3 - Chart of the 95\% Confidence Interval for Mean Costs According to Pain Type.

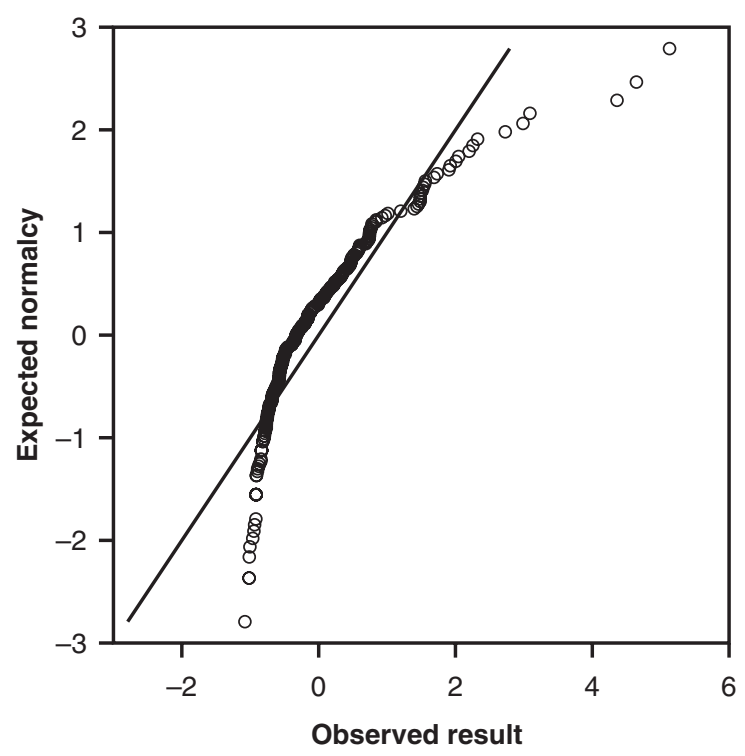

Figure 4 - Quartile-quartile Chart (QQPLOT).

\section{DISCUSSION}

The number of patients over a four-year period was small, but one should take into consideration that this study was not carried out in a pain clinic. The Alpha Center is an outpatient clinic for medical students in their rotation within the fifth year of undergraduation in which patients with chronic pain syndromes are scheduled in only two periods a week.

Basically, four economical analyses in health care can be made: cost-minimization, cost-benefit, cost-effectiveness, and cost-usefulness ${ }^{7,8}$. Cost-minimization analysis defines the in- tervention with the lower cost, while the other three establish relationships. In the present study, the mean monthly cost was calculated without considering the lower cost possible. The actual value was calculated comparing the cost with the pain classification.

Nociceptive pain results from the activation and sensitization of nociceptors. As a rule, it is associated with an actual damage, inflammatory process, trauma, or other cause that produces tissue damage or necrosis. Examples include pain due to bone metastasis and chronic inflammatory processes. Neuropathic pain is secondary to a partial lesion of the peripheral or central nervous system. It is frequently associated with allodynia and hyperalgesia. The most common syndromes include: peripheral neuropathies, medullary trauma after a stroke, and post-herpetic neuralgia. Mixed pain is present when those two mechanisms coexist, such as in lumbosciatalgia due to herniated lumbar disk.

Usually, a comparison of the mean costs by pain type is done using analysis of variance (ANOVA) that presupposes the normalcy of the data and homoscedasticity (equal variances among groups) verified, respectively, by the KolmogorovSmirnov and Levene tests. In the present study, the Kolmogorov-Smirnov test indicated a violation in data normalcy. Thus, comparison of the means by pain type was done using the non-parametric Kruskal-Wallis test.

Usually, analysis of cost-benefit establishes a relationship between economic resources spent and resources saved; cost-effectiveness analysis establishes the same relationship between economic resources spent and clinical effects produced; and cost-usefulness analysis establishes a relationship between resources spent and improvement in the quality of life. Economic analyses are constituted by two fundamental concepts: perspective of the analysis and type of clinical effectiveness analyzed ${ }^{9,10}$.

In the present study, only the monthly costs for control of chronic pain in patients treated regularly and who adhered to the treatment and appointments were analyzed.

This study demonstrated that the costs did not differ significantly considering the type of pain involved. In Figure 1 one can observe dissonant costs.

Chronic pain has considerable costs for society. Both direct medical costs and loss of productivity affect the economy. Costs also depend on the causes of chronic pain. Some studies have quantified the social costs attributable to neuropathic pain ${ }^{11-13}$. Several studies that compared the cost effectiveness of different treatment options for patients with neuropathic pain have been described in the literature 14-18. However, the present study was limited because other factors involved in the cost of chronic pain were not considered. Note that the cost of chronic pain does not involve only the cost of the drugs. Several other costs are involved such as medical appointments, complimentary exams, procedures (physiotherapy, psychotherapy, blocks, surgery), and hospitalization. 


\section{REFERÊNCIAS / REFERENCES}

01. Melo DO, Ribeiro E, Storpirtis S - A importância e a história dos estudos de utilização de medicamentos. RBCF Rev Bras Cienc Farm, 2006;42:475-485.

02. Lessard C, Contandriopoulos AP, Beaulieu MD - The role of economic evaluation in the decision-making process of family physicians: design and methods of a qualitative embedded multiple-case study. BMC Farm Pract, 2009;10:15.

03. Robertson J, Lang D, Hill S - Use of pharmacoeconomics in prescribing research. Part 1: costs-moving beyond the acquisition price for drugs. J Clin Pharm Ther, 2003;28:73-79.

04. Zanini AC, Farhat FCLG, Ribeiro E et al. - Farmacoeconomia: conceitos e aspectos operacionais. RBCF Rev Bras Cienc Farm, 2001;37:225-237.

05. Guillemin F, Bombardier C, Beaton D - Cross-cultural adaptation of health-related quality of life measures: literature review and proposed guidelines. J Clin Epidemiol, 1993;46:1417-1432.

06. Fitzpatrick R, Fletcher A, Gore S et al. - Quality of life measures in health care. I: Applications and issues in assessment. BMJ, 1992;305:1074-1077.

07. WHOQOL Group - The World Health Organization Quality of Life Assessment (WHOQOL): position paper from the World Health Organization. Soc Sci Med, 1995;41:1403-1409.

08. Shlipak MG - Análise de Decisão. em: Friedland - Medicina Baseada em Evidências: uma Estrutura para a Prática Clínica. Rio de Janeiro: Guanabara Koogan, 2001;32-51.

09. Cramer JA, Spilker B. Quality of Life and Pharmacoeconomics. Philadelphia: Lippincott-Raven, 1998;221-264.

10. Rittenhouse BE - Designing and Conducting Cost-Minimization and Cost-Effectiveness Analyses. em: Spilker B - Quality of Life and Pharmacoeconomics in Clinical Trials. Philadelphia, Lippincott-Raven, 1996;741-745.

11. Davies $L$, Cossins $L$, Bowsher $D$ et al. - The cost of treatment for postherpetic neuralgia in the UK. Pharmacoeconomics, 1994;6:142-148.

12. Manktelow RT, Binhammer P, Tomat LR et al. - Carpal tunnel syndrome: cross-sectional and outcome study in Ontario workers. J Hand Surg(Am), 2004;29:307-317.

13. ScottFT, JohnsonRW, Leedham-GreenMetal.-Theburden of herpeszoster: a prospective population based study. Vaccine 2006;27;24:1308-1314.
14. Cepeda MS, Farrar JT - Economic evaluation of oral treatments for neuropathic pain. J Pain. 2006;7:119-128.

15. O'Connor $A B-R e$ : sequential medication strategies for postherpetic neuralgia: a cost-effectiveness analysis. J Pain, 2007;8: 674-676.

16. Rodríguez MJ, Díaz S, Vera-Llonch $M$ et al. - Cost-effectiveness analysis of pregabalin versus gabapentin in the management of neuropathic pain due to diabetic polyneuropathy or post-herpetic neuralgia. Curr Med Res Opin, 2007;23:2585-2596.

17. Smith KJ, Roberts MS - Sequential medication strategies for postherpetic neuralgia: a cost-effectiveness analysis. J Pain, 2007;8:396-404.

18. Beard SM, McCrink L, Le TK et al. - Cost effectiveness of duloxetine in the treatment of diabetic peripheral neuropathic pain in the UK. Curr Med Res Opin, 2008;24:385-399.

Resumen: Vlainich R, Zucchi P, Issy AM, Sakata RK - Evaluación del Coste del Medicamento para el Tratamiento Ambulatorial de Pacientes con Dolor Crónico.

Justificativa y objetivos: El dolor crónico ocurre muy a menudo y el coste del tratamiento puede tener un impacto relevante en las personas y en la sociedad. El objetivo de este estudio fue evaluar los costes mensuales promedios de los medicamentos para el tratamiento ambulatorial del dolor crónico.

Método: En este estudio, analizamos el coste de los medicamentos utilizados por 233 pacientes con dolor crónico (117 con dolor nociceptivo, 59 con dolor neuropático y 57 con dolor mixto), y que fueron atendidos en el Centro Alfa de la UNIFESP, entre enero de 2004 y enero de 2008.

Resultados: El promedio general de los costes rondó los $\mathrm{R} \$ 127,74$ (coste mínimo de $\mathrm{R} \$ 5,00$ y máximo de $\mathrm{R} \$ 780,00$ ).

Conclusiones: El estudio reveló que los costes de medicamentos no son diferentes de forma significativa, teniendo en cuenta el tipo de dolor que existe. 